\title{
Purification and characterization of Antarctic krill chitinase and its role on free fluoride release from Antarctic krill cuticle
}

\author{
Wei JI ${ }^{1 \star}$ (D), Yuanhuai PENG ${ }^{2}$, Hongwu JI ${ }^{3,4}$
}

\begin{abstract}
To investigate factors that influence free fluoride release in Antarctic krill cuticle, the enzyme properties of a chitinase from Antarctic krill were analyzed to identify its role on free fluoride release from Antarctic krill cuticle. The chitinase was purified by ammonium sulfate precipitation,ion and gel chromatography, and identified by matrix-assisted laser desorption/ionization time-of-flight mass spectrometry (MALDI-TOF-MS). The molecular mass of the chitinase purified from Antarctic krill was $59.0 \mathrm{kDa}$ and its peptide sequences were similar to chitinase precursor sequences from Penaeus vannamei. The optimal $\mathrm{pH}$ of the chitinase was $\mathrm{pH} 6.5$ and temperature $45^{\circ} \mathrm{C}$ and exhibited high stability within $\mathrm{pH}$ 5.0-6.0 and temperatures below $35^{\circ} \mathrm{C}$. The chitinase activity was increased by $\mathrm{Ca}^{2+}$ and $\mathrm{Mg}^{2+}$, while inhibited by $\mathrm{Fe}^{2+}, \mathrm{Cu}^{2+}$ and $\mathrm{Co}^{2+}$. The purified chitinase had $\mathrm{Km}$ and Vmax values of $5.88 \mathrm{mmol} / \mathrm{L}$ and $2.11 \mu \mathrm{mol} / \mathrm{min} \cdot \mathrm{mL}$, respectively. The endogenous chitinase purified from Antarctic krill could degrade chitin fibers and induced the release of free fluoride from Antarctic krill cuticle. Under experimental conditions, the free fluoride release law in Antarctic krill cuticle can be described by equation: $C_{W}=\left[1-0.98 e^{-0.0111 t}-0.02 e^{0.15 t}\right] \times 175.52+10.80$.

Keywords: Antarctic krill cuticle; free fluoride; chitinase.

Practical Application: The purification and characterization of chitinase may get the pure chitinase relatively and know which enzyme was an important role for the release of free fluorine from Antarctic krill cuticle. The study about free fluoride release from Antarctic krill cuticle may help to know more about the reducing of fluoride in Antarctic krill. It may help to develop a more reliable and safe Antarctic krill.
\end{abstract}

\section{Introduction}

Antarctic krill (Euphausia superba) is the largest animal protein resource in the world with an amount of 379 million tons worldwide (Atkinson et al., 2009). Antarctic krill features high protein content (52\%) (Ji et al., 2021) and contains all nine indispensable amino acids for adults required by $\mathrm{FAO} / \mathrm{WHO} / \mathrm{UNU}$ (Young \& Pellett, 1991; Nicol et al., 2000). It is considered to be a nutrition-excellent food resource (Zhang et al., 2018).

Although Antarctic krill has a large biomass and high-quality proteins, only about $12 \%$ of the total krill is consumed by mankind. Currently, most of the krill is used for the manufacture of aquaculture feeds due to its high fluoride content (Torrecillas et al., 2021; Nunes et al., 2021). Antarctic krill contains 536-2,400 ppm fluoride in whole krill body, with 4.5-570 ppm in krill muscle and 1,800-4,260 ppm in krill cuticle respectively (Adelung et al.,1987; Sands et al., 1998). In living Antarctic krill, 99\% of the fluoride is concentrated in krill cuticle, while its content in krill muscle is negligible, which is similar to that of terrestrial vertebrates (Sands et al., 1998).

Fluoride is bound in molecular complexes in Antarctic krill cuticle, thus differing from the free forms of fluoride found in seawater. Sands et al. (1998) suggested that the fluoride in
Antarctic krill cuticle was related to the structural proteins; Peng et al. (2019) confirmed that the inorganic salt in Antarctic krill cuticle was fluorapatite. Adelung et al. (1987) found that the fluoride was concentrated in Antarctic krill cuticle and the fluoride in the soft tissue was almost negligible, which indicated that fluoride in living Antarctic krill could not migrate and was kept in stable binding forms. However, in postmortem storage, fluoride migrated from cuticle to the soft tissues, suggesting that the existing form of fluoride has been changed (Christians \& Leinemann, 1980). Free fluoride released by the cuticle is the most important cause of the increase of fluoride content in krill muscle, which has hindered the application of Antarctic krill protein in food production.

Antarctic krill is the most successful single species on the planet, a diversity of endogenous enzymes exist in Antarctic krill, including protease (Sun et al., 2021; Zhou et al., 2018), lipase (Chen et al., 2020), chitinase (El Knidri et al., 2018) and glucosidase (Turkiewicz et al., 2000), and so on. The endogenous enzymes play potential roles in the procedure of fluoride migration which can only be effectively prevented by low temperature $\left(-30^{\circ} \mathrm{C}\right)$ (Sands et al., 1998). 
Chitinase is the key enzyme causing postmortem autolysis of Antarctic krill (Ellingsen \& Mohr, 1987; Anheller et al.,1989). During the rapid autolysis process in krill postmortem, fluoride moves from the cuticle into the soft tissues where it accumulates with time (Christians \& Leinemann, 1980). Chitinase has been considered to be one of the main factors inducing fluoride migration. Fluoride concentration in the cuticle of Antarctic krill changes regularly with the molting cycle, starting from low values shortly post-molt, followed by a steep increase in the early stages, and reaching its peak upon the complete formation of the cuticle (Adelung et al., 1987). Chitinase activity also changed periodically with the molting cycle (Buchholz \& Buchholz, 1989). So chitinase can also be a factor in inducing free fluoride release and migration from Antarctic krill shell. To our knowledge, there is little reporting on the relationship between chitinase and free fluoride release from Antarctic krill cuticle.

In this study, endogenous chitinase was isolated, purified, identified and its characterization and potential impact on the free fluoride release from Antarctic krill cuticle was investigated. The results of this study will provide a foundation for inhibiting free fluoride release and migration in Antarctic krill.

\section{Materials and methods}

\subsection{Materials}

Antarctic krill (Euphausia superba) caught in Antarctic waters in March 2021, was provided by China National Fisheries Corporation, Overseas Fisheries Co., Ltd. (Beijing, China). The blocks were transported to laboratory at $-18{ }^{\circ} \mathrm{C}$. Upon arrival, they were stored at $-80^{\circ} \mathrm{C}$ till use. All chemical agents used in this study were of analytical grade.

Krill blocks were thawed at $4{ }^{\circ} \mathrm{C}$ and the cuticle and muscle were separated on ice. The adhering muscular tissue was carefully removed from the lateral parts of the fresh cuticle, minced and stored at $-80{ }^{\circ} \mathrm{C}$ until use.

\section{2 methods}

Isolation, purification and MALDI-TOF-MS identification of chitinase from Antarctic krill

Deep frozen $\left(-80^{\circ} \mathrm{C}\right)$ Antarctic krill was homogenized with an IKA homogenizer at $4{ }^{\circ} \mathrm{C}$ (IKA ${ }^{\oplus}$ Works, Guangzhou, China) in precooled Na-citrate-phosphate buffer (CPB, $0.2 \mathrm{~mol} / \mathrm{L}, \mathrm{pH}$ $5.5)$, with a $1: 2(\mathrm{w}: \mathrm{v})$ ratio of krill to buffer. After centrifugation $\left(10000 \times \mathrm{g}, 20 \mathrm{~min}, 4^{\circ} \mathrm{C}\right)$, crude chitinase contained in the supernatant was collected. The crude enzyme was fractionated by ammonium sulfate and the precipitate obtained was dissolved in $\mathrm{pH}$ 5.5, $20 \mathrm{mmol} / \mathrm{L}$ citrate-phosphate buffer (CPB) and dialyzed overnight against the same buffer ( $\mathrm{pH}$ 5.5). The enzyme solution was loaded on a Q-Sepharose F.F column $(2.6 \mathrm{~cm} \times 13 \mathrm{~cm}$, GE Healthcare, Fairfield. CT. USA) pre-equilibrated with phosphate buffer $(20 \mathrm{mmol} / \mathrm{L}, \mathrm{pH} 6.8)$, and eluted with $0-1 \mathrm{~mol} / \mathrm{L} \mathrm{NaCl}$ in the same buffer. The active fractions which showed chitinase activity were collected, concentrated with an ultra-filtration membrane (10 kDa, Millipore, Billerica, MA), and then applied to Sephacryl S200 column $(2.6 \mathrm{~cm} \times 13 \mathrm{~cm}$, GE Healthcare,
Fairfield. CT. USA) pre-equilibrated with phosphate buffer (20 mmol/L, pH 6.8) containing $50 \mathrm{mmol} / \mathrm{L} \mathrm{NaCl}$. The protein fractions were collected and analyzed for chitinase activity.

Polyacrylamide gel electrophoresis (SDS-PAGE) was performed to analyze the purity and molecular weight of purified chitinase. The electrophoresis voltage was set at $100 \mathrm{~V}$ at first and risen to $120 \mathrm{~V}$ once the bromine phenol blue front entered the separation gel. After electrophoresis, the gel was stained, decolorized, and analyzed on the gel imager.

The band of interest was removed from the gel and digested by trypsin. The sample was mixed with matrix solution. Mass spectra were recorded on a matrix-assisted laser desorption/ ionization time-of-flight mass spectrometer (MALDI-TOF-MS, Bruker Daltonics, Karlsruhe, Germany), which was equipped with a nitrogen laser. The fragment spectra were obtained in the positive mode and identification and the correlation of possible similarities with proteins present in the database was determined automatically by the algorithm Mascot (Rigueira et al., 2016).

\section{Chitinase activity assay and protein determination}

The formation of $\mathrm{p}$-nitrophenol from $\mathrm{p}$-nitrophenyl-Nacetyl- $\beta$-D-glucosaminide was taken as a quantitative indicator for chitinase activity. A volume of $50 \mu \mathrm{L}$ of $0.2 \mathrm{~mol} / \mathrm{L} \mathrm{CPB}$, $\mathrm{pH} 5.5$, was incubated with $50 \mu \mathrm{L}$ substrate solution $(0.3 \%$, $\mathrm{w} / \mathrm{v}$ ) and $50 \mu \mathrm{L}$ of sample was incubated for $15 \mathrm{~min}$ at $35^{\circ} \mathrm{C}$. The reaction was stopped by the addition of $2.5 \mathrm{~mL}$ of $0.01 \mathrm{~mol} / \mathrm{L}$ $\mathrm{NaOH}$. Blanks were added with stop solution and then enzyme sample. The absorbance of samples and blanks was read at $410 \mathrm{~nm}$. One unit of chitinase activity (U) was defined as the amount of the enzyme which catalyzed the release of $1 \mu \mathrm{mol}$ of p-nitrophenol per minute per milliliter. The protein concentration was determined by the Bradford method, using bovine serum albumin as a standard. Specific activity was expressed as units per milligram of protein.

\section{Properties of the purified chitinase}

The optimum temperature was determined by assaying the chitinase activity at various temperatures $\left(0-75^{\circ} \mathrm{C}\right)$ for $60 \mathrm{~min}$ in $\mathrm{CPB}(0.2 \mathrm{~mol} / \mathrm{L}, \mathrm{pH} 5.5)$. The thermostability of the enzyme was determined by pre-incubating the enzyme at various temperatures ranging from 0 to $75^{\circ} \mathrm{C}$. Aliquots were withdrawn and allowed to cool and the enzyme assay procedure described above was followed.

The optimum $\mathrm{pH}$ for the purified chitinase was detected by analyzing its activity over a $\mathrm{pH}$ range of 3.5-7.5 using $0.2 \mathrm{~mol} / \mathrm{L}$ $\mathrm{CPB}$. The stability of the enzyme at varying $\mathrm{pH}$ was determined by pre-incubating the purified enzyme in the buffers mentioned above for $1 \mathrm{~h}$ at $4{ }^{\circ} \mathrm{C}$ and subsequently analyzed the residual activity under standard assay conditions. The experiments were performed in triplicates and their mean value was utilized for activity calculations.

Effects of various metal ions $\left(\mathrm{Fe}^{2+}, \mathrm{Zn}^{2+}, \mathrm{Ba}^{2+}, \mathrm{Mg}^{2+}, \mathrm{Mn}^{2+}, \mathrm{Cd}^{2+}\right.$, $\left.\mathrm{Ca} 2+, \mathrm{Cu}^{2+}, \mathrm{Co}^{2+}\right)$ and EDTA on chitinase activity were studied by pre-incubating the purified enzyme in $\mathrm{CPB}(0.2 \mathrm{~mol} / \mathrm{L}, \mathrm{pH} 5.5)$ with metal ions $(10 \mathrm{mmol} / \mathrm{L})$. After incubation for $1 \mathrm{~h}$ at $4{ }^{\circ} \mathrm{C}$, residual enzyme activity was measured under the standard assay 
conditions. The enzyme activity obtained without the addition of any metal ion was set as $100 \%$ for comparison purposes.

Substrate specificity and kinetics parameters. The effect of the concentration of substrate was determined by measuring the enzyme activity on a broad substrate concentration in $\mathrm{CPB}$ (0.2 mol/L, pH 6.5).

The kinetic parameters of the purified chitinase were determined by measuring the enzyme activity at different concentrations $(0.5-1.4 \mathrm{mmol} / \mathrm{L})$ of p-nitrophenyl- $\mathrm{N}$-acetyl- $\beta$ $\mathrm{D}$-glucosaminide. The assay was conducted in triplicates, The $\mathrm{V}_{\max }$ and $\mathrm{K}_{\mathrm{m}}$ were estimated through the linear regression plots of Lineweaver and Burk.

Role of purified chitinase on free fluoride release from Antarctic krill cuticle

An amount of $2.0 \mathrm{~g}$ krill cuticle was placed in a $50 \mathrm{~mL}$ plastic centrifuge tube and the chitinase solution was added. Buffer solution (phosphate buffer, $20 \mathrm{mmol} / \mathrm{L}, \mathrm{pH}$ 6.8) was used as a negative control. The ratio of cuticle to enzyme solution was 1:15 (W: V). The content was kept at $20^{\circ} \mathrm{C}$, and the fluoride content was detected every two hours by the standard fluoride selective ion electrode method (Guo et al., 2017).

Kinetics of free fluoride release from Antarctic krill cuticle by the hydrolysis of chitinase

The first-order kinetic equation was employed to construct the fluoride release kinetics based on the amount of free fluoride released from the digestion of Antarctic krill cuticle. The mathematical simulation was carried out with MATLAB software.

\section{Determination of acetylglucosamine content}

Determination of acetylglucosamine content in the solution was conducted according to Imoto \& Yagishita (1971).

\section{Determination of fluoride content}

The fluoride concentration of samples was determined using a fluoride ion-selective electrode (ISE) according to a standard addition method reported by Yao et al. (2021).

\section{Data analysis}

Values were expressed as the mean (standard deviation of three parallel measurements). Differences between variables were tested for significance by one-way ANOVA using SPSS 19.0 (SPSS Inc., Chicago, IL). P $<0.05$ was considered to be statistically significant. MATLAB statistical software was used to regression fitting the kinetic equation.

\section{Results and discussion}

\subsection{Isolation, purification and identification of chitinase}

The crude enzyme precipitated by ammonium sulfate was purified using Q-Sepharose F.F column and Sephacryl S200 column (Figure 1). The purified chitinase showed a single band by SDS-PAGE analysis, whose apparent molecular mass was $59.0 \mathrm{kDa}$ (Figure 2). The specific activity of chitinase was increased 1.54 folds after $\left(\mathrm{NH}_{4}\right)_{2} \mathrm{SO}_{4}$ precipitation, chromatography, whose purity was greatly increased (102.94-fold) with a recovery of $16.11 \%$ and the final specific activity was getting to $6.56 \mathrm{U} / \mathrm{mg}$ on average (data not shown).

The purified chitinase from Antarctic krill showed sequence similarity with chitinase precursor from Penaeus vannamei [ACG60513.1], the peptide matches are shown in Table 1. Results showed that the purified chitin hydrolase was endogenous chitinase.

\subsection{Characterization of purified chitinase}

\section{Optimal temperature and $p H$}

Temperature and $\mathrm{pH}$ play important roles in enzyme activity and stability. The purified enzyme exhibited activity between 20-60 ${ }^{\circ} \mathrm{C}$, its optimal temperature being $45^{\circ} \mathrm{C}$ (Figure $3 \mathrm{~A}$ ), and had good thermostability at temperatures below $35^{\circ} \mathrm{C}$ (Figure 3B). Spindler \& Buchholz (1988) reported that the optimal temperature for chitinase in Euphausia superba was
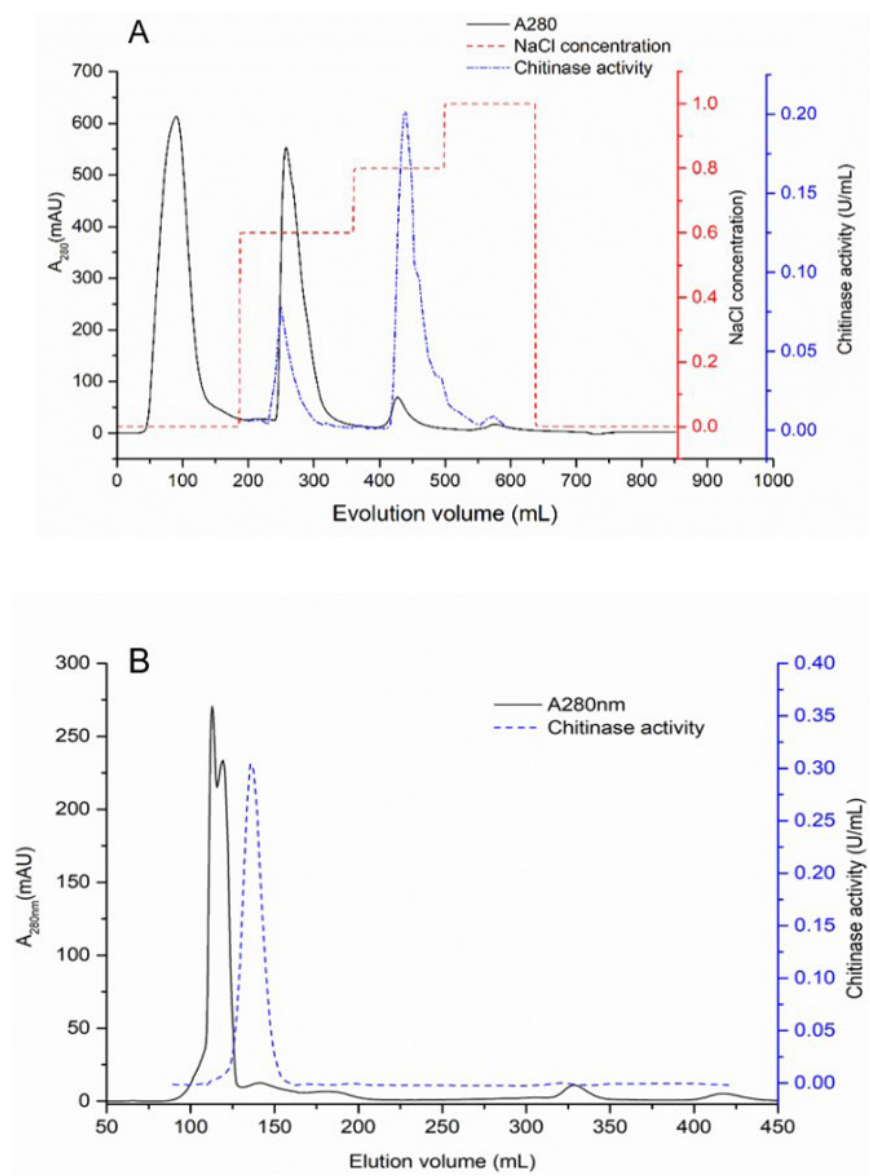

Figure 1. Chromatographic purification of Antarctic krill chitinase. (A) Elution profile of the ammonium sulfate precipitated fraction from chromatography over a Q-Sepharose Fast Flow column; (B) Sephacryl S-200 gel filtration column. 


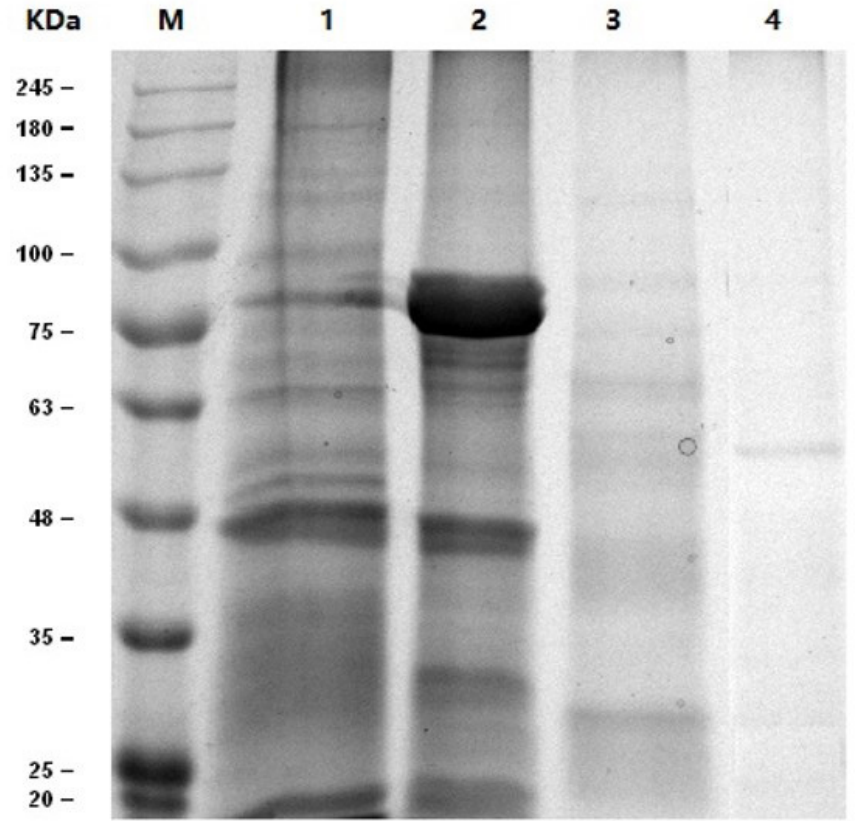

Figure 2. SDS-PAGE of endogenous chitinase in Antarctic krill (M: marker; 1: crude enzyme; 2: Dialysate: 3: Q-Sepharose F.F; 4: Sephacryl S200).
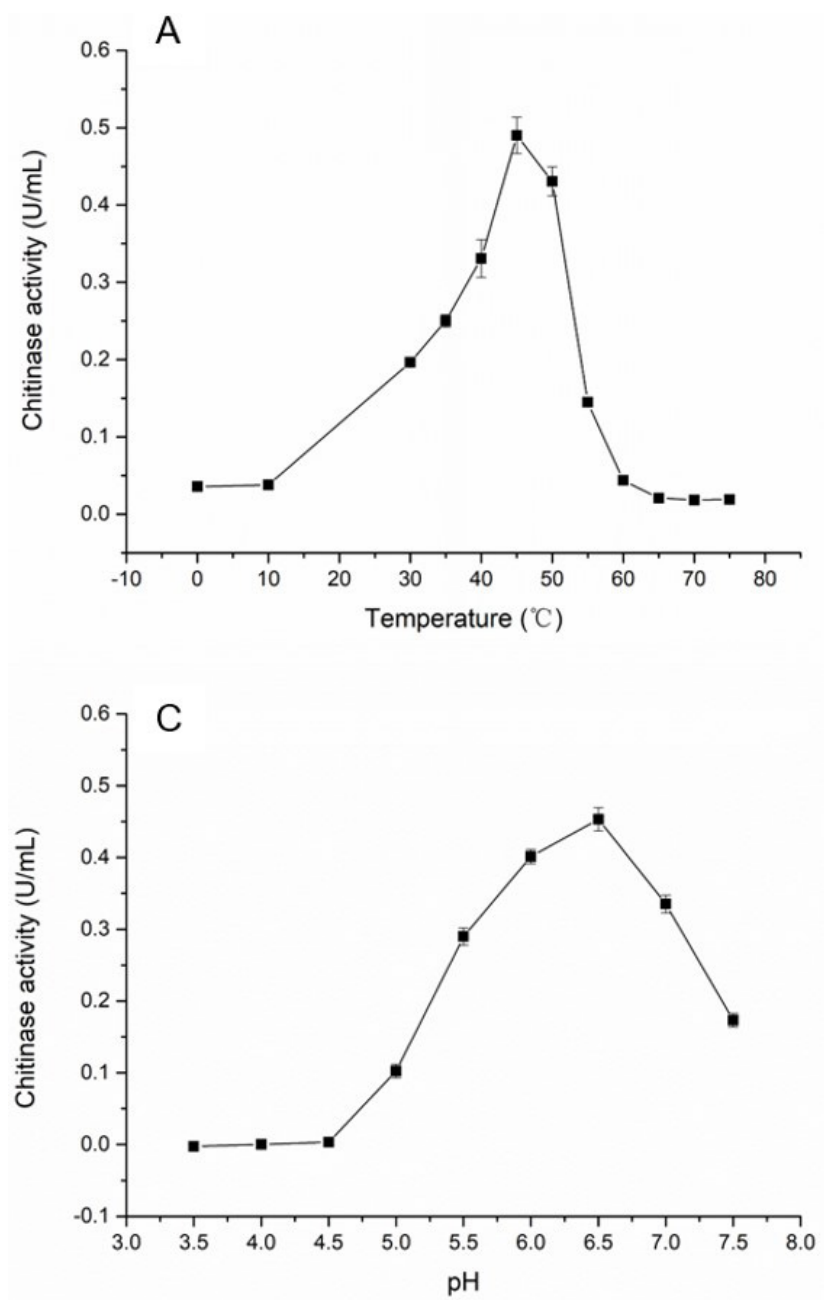

$45^{\circ} \mathrm{C}$ and stable below $30^{\circ} \mathrm{C}$, and the enzyme was destroyed at $60{ }^{\circ} \mathrm{C}$. The optimal temperature range for chitinase is $40-50{ }^{\circ} \mathrm{C}$ (Karthik et al., 2015; Mander et al., 2016). The results of this study were consistent with these reports. No chitinase activity can be detected from Locusta migratoria chitinase below $20^{\circ} \mathrm{C}$ (Zielkowski \& Spindler, 1978). However, in the present study, the chitinase activity can be detected at low temperature, even at $0{ }^{\circ} \mathrm{C}$. The reason may be that the enzymes of Antarctic krill have adapted to the low-temperature environment. T

The enzyme was active between $\mathrm{pH}$ 5.0-7.0 and showed maximum activity at $\mathrm{pH} 6.5$ in $0.2 \mathrm{~mol} / \mathrm{L} \mathrm{CPB}$ (Figure 3C). Almost no chitinase activity was detectable under $\mathrm{pH} 4.5$. From $\mathrm{pH} 5.0$ to 7.5 , the activity was higher than those at other $\mathrm{pH}$ values, indicating that the enzyme was active in a neutral environment. The enzyme displayed stability in the range of $\mathrm{pH}$ 5.0-6.0 as more than $84 \%$ of its activities were maintained after it was treated in different buffers (Figure 3D). The poor stability in an acidic environment indicated the denaturation of the chitinase because the loss of activity due to $\mathrm{pH}$ in this work was, to some degree, irreversible over a certain $\mathrm{pH}$ range. Spindler \& Buchholz (1988) reported that the chitinase in Antarctic krill showed the highest activity at $\mathrm{pH} 6.0$, the present results were similar to this research. While the chitinase from Streptomyces
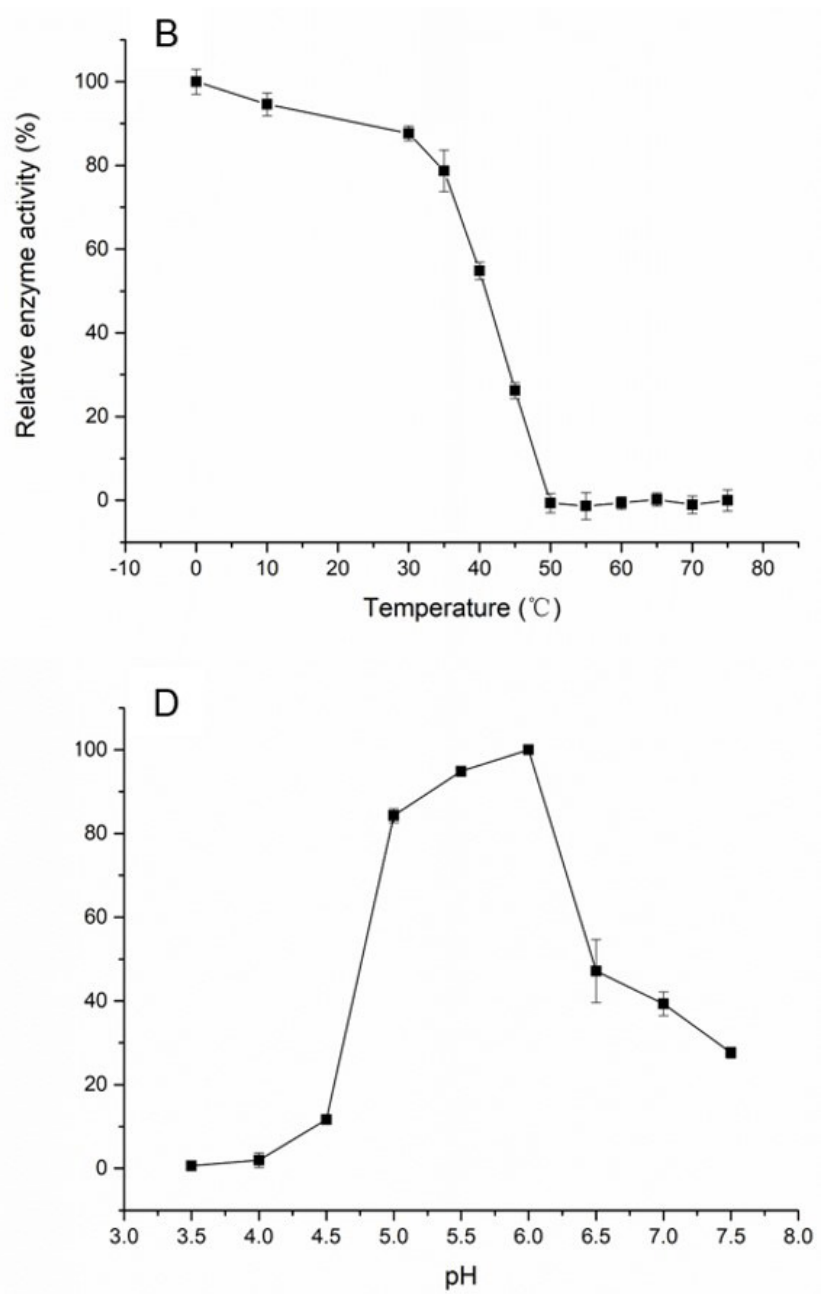

Figure 3. Characterization of purified chitinase. (A) optimal temperature; (B) thermal stability; (C) optimal pH; (D) pH stability. 
sp. CS495 was active from pH 8.0 to 13.6 with the highest activity at $\mathrm{pH} 12.5$ (Meena et al., 2014). The chitinase produced by Humicola grisea had optimum activity at a relatively lower pH 3.0 (Kumar et al., 2018). Chitinases from different sources differ significantly in their properties.

\section{Effects of metal ions and EDTA on chitinase activity}

Metal ions play important roles in biological catalysis (Han et al., 2009). The influence of metal ions was illustrated

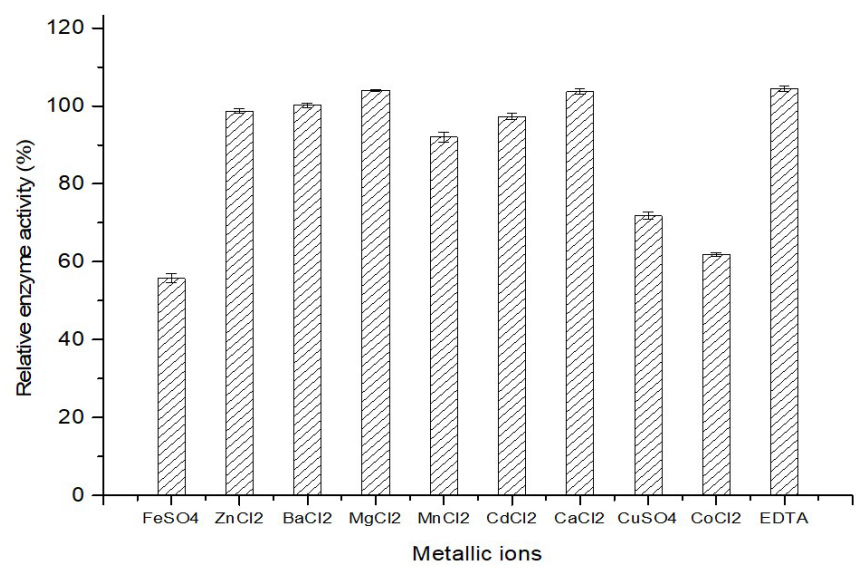

Figure 4. Effects of metal ions and EDTA on chitinase activity. in Figure 4. With $10 \mathrm{mM}$ of tested elements, none of the metal ions tested provided good activation of the chitinase. This result was similar to that of chitinase from Streptomyces violaceusniger and Paenibacillus pasadenensis (Fu et al., 2016; Guo et al., 2017). The chitinase activity was enhanced mildly by $\mathrm{Ca}^{2+}$ and $\mathrm{Mg}^{2+}$ and strongly inhibited by $\mathrm{Fe}^{2+}, \mathrm{Cu}^{2+}$ and $\mathrm{Co}^{2+}$, whereas no significantly different rates for $\mathrm{Zn}^{2+}, \mathrm{Ba}^{2+}, \mathrm{Mn}^{2+}, \mathrm{Cd}^{2+}$ were observed. Fu et al. (2016) reported that $\mathrm{Ca}^{2+}$ and $\mathrm{Mg}^{2+}$ activated chitinase activity and $\mathrm{Co}^{2+}$ inhibited.

EDTA, a chelating agent capable of binding metal ions in solution, showed no inhibition of the chitinase activity, suggesting that the chitinase in Antarctic krill was not a metal-enzyme (Guo et al., 2017). As opposed to the chitinase from Antarctic krill, the activity of chitinase from marine-derived Aspergillus terreus was inhibited by the treatment with EDTA (Farag et al., 2016).

\section{Effect of the concentration of substrate and kinetic parameters}

The effect of the concentration of substrate on the activity of chitinase was shown in Figure 5A. The chitinase was inhibited by an excess of substrate. Spindler \& Buchholz (1988) reported that the activity of chitinase from Meganyctiphanes norvegica decreased at high substrate concentration. To investigate the enzymatic action of this chitinase, the kinetic parameters of the purified chitinase were studied using $\mathrm{p}$-nitrophenyl-N-acetyl- $\beta$ $\mathrm{D}$-glucosaminide as substrate. Kinetic parameters were obtained from Lineweaver-Burk double reciprocal plots (Figure 5B).
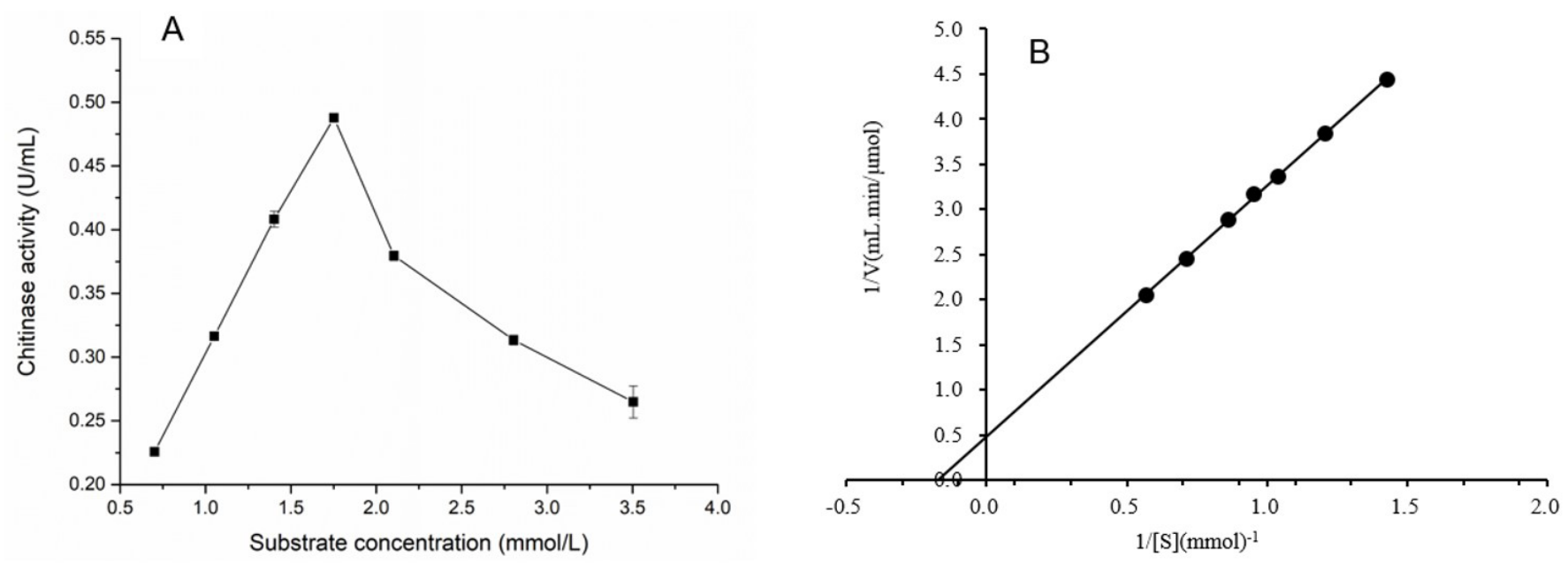

Figure 5. Effect of the concentration of substrate and kinetic parameters. (A) effect of the concentration of substrate on the activity of chitinase; (B) Lineweaver-Burk plots of the purified chitinase.

Table 1. Identification of chitinase by MALDI-TOF-MS.

\begin{tabular}{cccc}
\hline Protein & Peptide sequence & Identified protein & Accession number \\
\hline Purified chitinase & KLVXELRE & chitinase 1 precursor (Penaeus & ACG60513.1 \\
& KGIPRSGKA & vannamei) & \\
KLVHNKAPRA & \\
RRPGLXEWAY & \\
WV GFADVHSMLY & \\
& VPFTHKGDQWVGYEDPDSLK & \\
APTLPPTTTN SWWTPPTTTT & \\
\hline
\end{tabular}


The $\mathrm{K}_{\mathrm{m}}$ and $\mathrm{V}_{\max }$ values are $5.88 \mathrm{mmol} / \mathrm{L}$ and $2.11 \mu \mathrm{mol} / \mathrm{min} \cdot \mathrm{mL}$, respectively.

\subsection{Role of purified chitinase on free fluoride release from Antarctic krill cuticle}

The purified chitinase was used to investigate the relationship between chitinase activity and free fluorine release from Antarctic krill cuticle. Data showed that the concentration of fluoride ions in the solution increased rapidly within $6 \mathrm{~h}$ post-hydrolysis and entered an equilibrium phase from $8 \mathrm{~h}$ on (Figure 6A). The concentration of acetylglucosamine increased with the hydrolysis of chitinase (Figure 6B), this indicated that parallel to the increasing of free fluoride concentration in the solution, chitin fibers in the cuticle samples were decomposed.

During the molting process of Antarctic krill, chitinases are secreted to the cuticle where they degrade the chitin fibers. Chitin content in the old cuticle is reduced by about $50 \%$ while molting completes (Spindler-Barth, 1976), and the chitin degradation products will then be transported back to the body for resynthesizing new chitin fiber (Gwinn \& Stevenson, 1973). With the degradation of the cuticle, fluoride in the old cuticle quickly dissolves and dissipates, thus causing the fluoride content to decrease rapidly (Adelung et al., 1987).

Chitin is hydrolyzed by $\mathrm{N}$-acetylglucosaminidase, which specifically breaks $\beta-1,4$ glycosidic bonds and is one of the main causes of its degradation. Endochitinase degrades chitin in the cuticle of crustaceans to oligosaccharides, which are then degraded by acetylglucosaminidase to produce acetylglucosamine monomer, the precursor of chitin (Buchholz \& Vetter, 1993). Chitinase is expressed in distributes in the epidermis and digestive tract of Antarctic krill (Peters et al., 1999). The highest expression level of chitinase is at the middle stage of molting before the cracks between the old and new cuticle appearance (Seear et al., 2010). It is reported that chitinase was secreted into the outer of the cuticle to degrade chitin (Buchholz \& Buchholz, 1989). After the death of Antarctic krill, the chitin-degrading enzymes in the cuticle can degrade the chitin fiber and destroy the structure of the cuticle. Results showed chitinase triggered the transformation of the fluoride forms and induced free fluoride release from Antarctic krill cuticle.

\subsection{Kinetic of free fluoride release from Antarctic krill cuticle hydrolyzed by chitinase}

The release of free fluoride from the cuticle includes two stages: the initial rapid release phase and the subsequent slow release phase. The release rates can be described by the following equation:

$$
\begin{aligned}
& R=1-S_{t} / S_{0} ; S_{t}=S_{0}\left[H e^{-K_{1} t}+(1-H) e^{-K_{2} t}\right] \\
& R=1-H e^{-K_{1} t}-(1-H) e^{-K_{2} t}
\end{aligned}
$$

In Equations 1 and 2, $\mathrm{R}$ is the release rate of free fluoride in Antarctic krill cuticle at time t. $S_{t}$ is the total amount of free fluoride in Antarctic krill cuticle at time t $(\mu \mathrm{g} / \mathrm{g}) . S_{0}$ is the total amount of free fluoride in Antarctic krill cuticle at $\mathrm{t}=0(\mu \mathrm{g} / \mathrm{g})$, that is, the total amount of free fluoride in Antarctic krill cuticle. $\mathrm{H}$ is free fluorine released quickly from the cuticle. $K_{1}$ is the first-order release constant of the rapid release stage in Antarctic krill cuticle.1-H is free fluoride released slowly from shrimp shell. ${ }^{K_{2}}$ is the first-order release constant of the slow release stage in Antarctic krill cuticle and $\mathrm{t}$ is time (h).

Since the enzyme solution used here did not contain fluoride ions, the amount of free fluoride released by the hydrolysis of krill cuticle by endogenous chitinase equals the amount of fluoride ions in the solution minus the fluoride ions at $0 \mathrm{~h}$. Then the following equation holds:

$\left[1-H e^{-K_{1} t}-(1-H) e^{-K_{2} t}\right] \times Q_{S}=\left(C_{W}-C_{0}\right) V_{W}$

From Equation 3:

$C_{W}=\left[1-H e^{-K_{1} t}-(1-H) e^{-K_{2} t}\right] \times Q_{S} / V_{W}+C_{0}$

where $C_{W}$ is the total amount of free fluoride in Antarctic krill cuticle at time $\mathrm{t}(\mu \mathrm{g} / \mathrm{g}) . Q_{S}$ is the total amount of free fluoride in Antarctic krill cuticle that can be released by chitinase $(\mu \mathrm{g} / \mathrm{g})$. $V_{W}$ is the volume of the solution.

The total amount of free fluoride in Antarctic krill cuticle can be calculated by Equation (5).

$Q_{S}=P \times N \times F_{t}$

where $\mathrm{P}$ is the weight of Antarctic krill cuticle (g). $\mathrm{N}$ is the ratio of fluoride released by chitinase to the total fluoride in Antarctic krill cuticle; $F_{t}$ is total fluoride in Antarctic krill cuticle $(\mu \mathrm{g} / \mathrm{g})$.

The Equation 4 is transformed into:

$C_{W}=\left[1-H e^{-K_{1} t}-(1-H) e^{-K_{2} t}\right] \times P \times N \times F_{t}+C_{0}$

The Equation 6 presents the change of the free fluoride content in the solution with the hydrolysis duration, $\mathrm{H}, \mathrm{N}, \mathrm{Ft}, \mathrm{P}$ and was $0.98,0.13,675.06,2.0$, and 10.80 , respectively. The kinetic expression of free fluoride released from Antarctic krill cuticle by chitinase hydrolysis is:

$C_{W}=\left[1-0.98 e^{-K_{1} t}-0.02 e^{-K_{2} t}\right] \times 175.52+10.80$

MATLAB statistical software was used to perform nonlinear regression fitting on the free fluoride release data from krill cuticle hydrolyzed by chitinase, and the values of release rates $\mathrm{K}_{1}$ and $\mathrm{K}_{2}$ were 0.0111 and -0.1500 ,respectively. Regression coefficient $\mathrm{R}^{2}$ was 09529. Substituting the rate constant into the Equation 7:

$C_{W}=\left[1-0.98 e^{-0.0111 t}-0.02 e^{0.15 t}\right] \times 175.52+10.80$

Equation 8 is the kinetic equation of free fluoride released from Antarctic krill cuticle hydrolyzed by chitinase.

To verify the kinetic model of free fluoride release from Antarctic krill cuticle, the data calculated by the model and the data obtained from experiment results were compared. As seen 

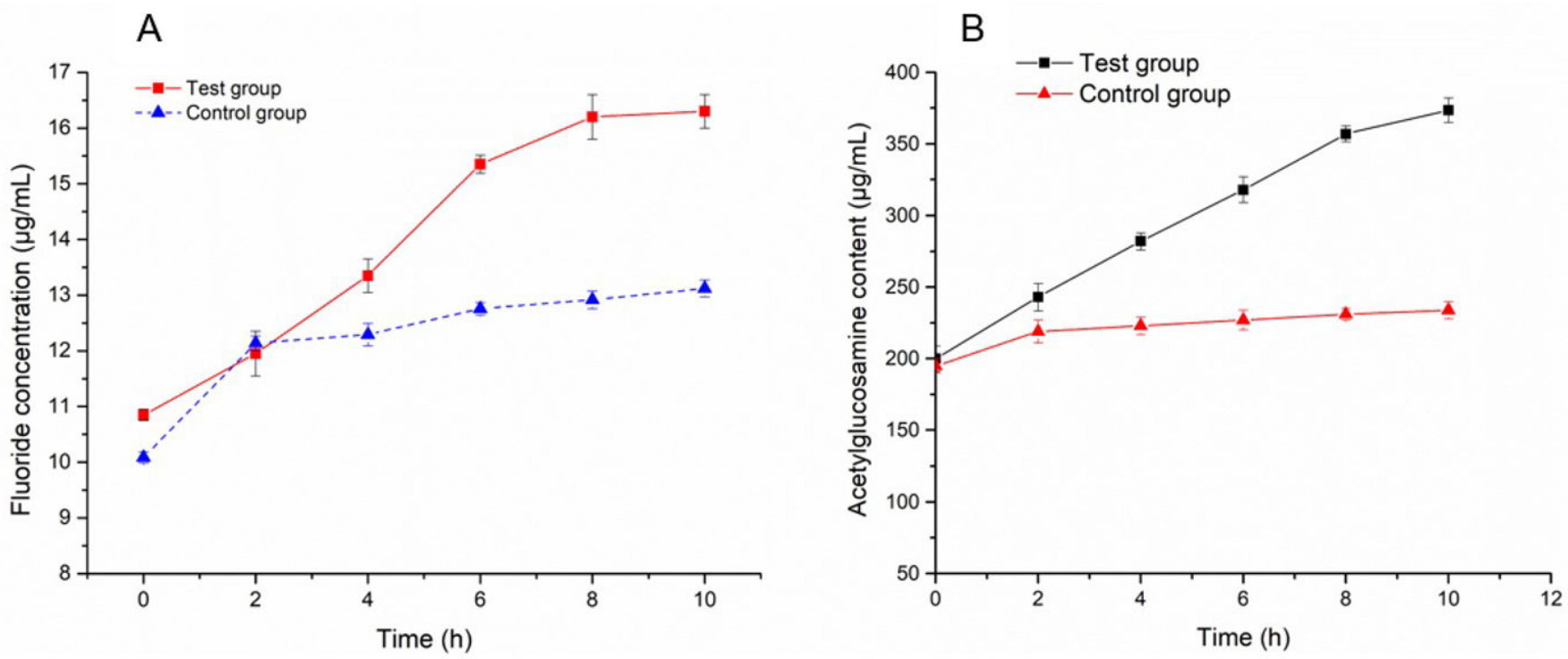

Figure 6. Effects of purified endogenous chitinase on the hydrolysis of Antarctic krill cuticle. (A) changes of free fluoride release; (B) changes of acetylglucosamine content.

Table 2. Validation on a kinetic model of free fluoride release from Antarctic krill cuticle by chitinase.

\begin{tabular}{ccccc}
\hline Endogenous hydrolase & Reaction time $(\mathrm{h})$ & Predicted value $(\mu \mathrm{g} / \mathrm{g})$ & Measured value $(\mu \mathrm{g} / \mathrm{g})$ & Relative error $(\%)$ \\
\hline chitinase & 2 & 13.35 & 12.42 & 7.5 \\
& 6 & 16.76 & 15.92 & 5.3 \\
& 8 & 17.27 & 16.15 & 6.9 \\
& 10 & 16.65 & 16.35 & 1.8 \\
\hline
\end{tabular}

from Table 2, the data from the two approaches were comparable, suggesting that the established kinetic model can accurately describe the process parameters of free fluoride release from Antarctic krill cuticle hydrolyzed by chitinase.

\section{Conclusion}

The chitinase purified from Antarctic krill had a molecular weight of $59.0 \mathrm{kDa}$ with an optimal activity at pH 6.5 and temperature $45^{\circ} \mathrm{C}$ and showed high stability within pH 5.0-6.0 and temperatures below $35^{\circ} \mathrm{C}$. Both $\mathrm{Ca}^{2+}$ and $\mathrm{Mg}^{2+}$ ions stimulated enzyme activity, while $\mathrm{Fe}^{2+}, \mathrm{Cu}^{2+}$ and $\mathrm{Co}^{2+}$ had inhibitory effects on the enzyme. The chitinase can degrade Antarctic cuticle chitin fibers and increase the free fluoride release. The results will benefit for inhibiting free fluoride release and migration during Antarctic krill postmortem storage and for the development and utilization of Antarctic krill and its chitinase.

\section{Ethical approval}

All applicable international, national, and/or institutional guidelines for the care and use of animals were followed.

\section{Conflict of interest}

The authors are not aware of any conficts of interest which may arise as a result of this work.

\section{Funding}

This work was co-supported by the National Natural Science Foundation of China (grant No. 31801614), the Modern Agroindustry Technology Research System of China (CARS-48) and Guangdong Provincial Key Laboratory of Aquatic Product Processing and Safety (GDPKLAPPS2005).

\section{Author contributions}

Wei Ji performed the experiments and wrote the article; Yuanhuai Peng performed experiments; Hongwu Ji reviewed the manuscript.

\section{References}

Adelung, D., Buchholz, F., Culik, B., \& Keck, A. (1987). Fluoride in tissues of krill Euphausia superba Dana and Meganyctiphanes norvegica $\mathrm{M}$ Sars in relation to the moult cycle. Polar Biology, 7(1), 43-50. http:// dx.doi.org/10.1007/BF00286823.

Anheller, J. E., Hellgren, L., Karlstam, B., \& Vincent, J. (1989). Biochemical and biological profile of a new enzyme preparation from Antarctic krill (E. superba) suitable for debridement of ulcerative lesions. Archives of Dermatological Research, 281(2), 105-110. http://dx.doi. org/10.1007/BF00426587. PMid:2774638.

Atkinson, A., Siegel, V., Pakhomov, E. A., Jessopp, M. J., \& Loeb, V. (2009). A re-appraisal of the total biomass and annual production of Antarctic krill. Deep-sea Research. Part I, Oceanographic Research Papers, 56(5), 727-740. http://dx.doi.org/10.1016/j.dsr.2008.12.007. 
Buchholz, C., \& Buchholz, F. (1989). Ultrastructure of the integument of a pelagic Crustacean: moult cycle related studies on the Antarctic krill. Euphausia superba. Marine Biology, 101(3), 355-365. http:// dx.doi.org/10.1007/BF00428132.

Buchholz, F., \& Vetter, R. A. H. (1993). Enzyme kinetics in cold water: characteristics of $\mathrm{N}$-acetyl- $\beta$-D-glucosaminidase activity in the Antarctic krill, Euphausia superba, compared to other crustacean species. Journal of Comparative Physiology. B, Biochemical, Systemic, and Environmental Physiology, 163(1), 28-37. http://dx.doi. org/10.1007/BF00309662.

Chen, X., Wang, C., Xu, J., Wang, F., Jiang, Y., Chen, Y., \& Zhao, X. (2020). Purification and characterization of a novel lipase from Antarctic krill. Journal of Ocean University of China, 19(1), 209-219. http://dx.doi.org/10.1007/s11802-020-4174-1.

Christians, O., \& Leinemann, M. (1980). Untersuchungen über fluor im krill (Euphausia superba Dana). Inf Fischwirtschaft, 6, 254-260.

El Knidri, H., Belaabed, R., Addaou, A., Laajeb, A., \& Lahsini, A. (2018). Extraction, chemical modification and characterization of chitin and chitosan. International Journal of Biological Macromolecules, $120(\mathrm{Pt}$ A), 1181-1189. http://dx.doi.org/10.1016/j.ijbiomac.2018.08.139. PMid:30172808.

Ellingsen, T. E., \& Mohr, V. (1987). Biochemistry of the autolytic processes in Antarctic krill post mortem. Autoproteolysis. The Biochemical Journal, 246(2), 295-305. http://dx.doi.org/10.1042/ bj2460295. PMid:3689312.

Farag, A. M., Abd-Elnabey, H. M., Ibrahim, H. A. H., \& El-Shenawy, M. (2016). Purification, characterization and antimicrobial activity of chitinase from marine-derived Aspergillus terreus. Egyptian Journal of Aquatic Research, 42(2), 185-192. http://dx.doi.org/10.1016/j. ejar.2016.04.004.

Fu, X., Yan, Q., Wang, J., Yang, S., \& Jiang, Z. (2016). Purification and biochemical characterization of novel acidic chitinase from Paenicibacillus barengoltzii. International Journal of Biological Macromolecules, 91, 973-979. http://dx.doi.org/10.1016/j.ijbiomac.2016.06.050. PMid:27320843.

Guo, X., Xu, P., Zong, M., \& Lou, W. (2017). Purification and characterization of alkaline chitinase from Paenibacillus pasadenensis CS0611. Chinese Journal of Catalysis, 38(4), 665-672. http://dx.doi. org/10.1016/S1872-2067(17)62787-6.

Gwinn, J. F., \& Stevenson, J. R. (1973). Role of acetylglucosamine in chitin synthesis in crayfish-I. Correlation of 14C-acetylglucosamine incorporation with stages of the molting cycle. Comparative Biochemistry and Physiology. B, Comparative Biochemistry, 45(4), 769-776. http:// dx.doi.org/10.1016/0305-0491(73)90138-7. PMid:4727858.

Han, Y., Yang, B. J., Zhang, F. L., Miao, X. L., \& Li, Z. Y. (2009). Characterization of antifungal chitinase from marine streptomyces sp. DA11 associated with South China Sea sponge Craniella Australiensis. Marine Biotechnology, 11(1), 132-140. http://dx.doi.org/10.1007/ s10126-008-9126-5. PMid:18626709.

Imoto, T., \& Yagishita, K. (1971). A simple activity measurement of lysozyme. Agricultural and Biological Chemistry, 35(7), 1154-1156. http://dx.doi.org/10.1080/00021369.1971.10860050.

Ji, W., Zhang, C., Song, C., \& Ji, H. (2021). Three DPP-IV inhibitory peptides from Antarctic krill protein hydrolysate improve glucose levels in the zebrafish model of diabetes. Food Science and Technology. In press. http://dx.doi.org/10.1590/fst.58920.

Karthik, N., Binod, P., \& Pandey, A. (2015). Purification and characterisation of an acidic and antifungal chitinase produced by a Streptomyces sp. Bioresource Technology, 188, 195-201. http://dx.doi.org/10.1016/j. biortech.2015.03.006. PMid:25824594.
Kumar, M., Brar, A., Vivekanand, V., \& Pareek, N. (2018). Process optimization, purification and characterization of a novel acidic, thermostable chitinase from Humicola grisea. International Journal of Biological Macromolecules, 116, 931-938. http://dx.doi.org/10.1016/j. ijbiomac.2018.05.125. PMid:29782982.

Mander, P., Cho, S. S., Choi, Y. H., Panthi, S., Choi, Y. S., Kim, H. M., \& Yoo, J. C. (2016). Purification and characterization of chitinase showing antifungal and biodegradation properties obtained from Streptomyces anulatus CS242. Archives of Pharmacal Research, 39(7), 878-886. http://dx.doi.org/10.1007/s12272-016-0747-3. PMid:27215829.

Meena, S., Gothwal, R. K., Krishna Mohan, M., \& Ghosh, P. (2014). Production and purification of a hyperthermostable chitinase from Brevibacillus formosus BISR-1 isolated from the Great Indian Desert soils. Extremophiles, 18(2), 451-462. http://dx.doi.org/10.1007/ s00792-014-0630-4. PMid:24473902.

Nicol, S., Forster, I., \& Spence, J. (2000). Products derived from krill. In I. Everson (Ed.), Krill: biology, ecology and fisheries (pp. 262-283). Oxford: Blackwell Science. http://dx.doi.org/10.1002/9780470999493.ch10.

Nunes, A., Soares, A. N., Sabry-Neto, H., \& Burri, L. (2021). Effect of dietary graded levels of astaxanthin krill oil and high protein krill meal on the growth performance and stress resistance of post larval litopenaeus vannamei under hyper-intensive nursery culture. Aquaculture Nutrition, 27(2), 327-341. http://dx.doi.org/10.1111/ anu.13187.

Peng, Y., Ji, W., Zhang, D., Ji, H., \& Liu, S. (2019). Composition and content analysis of fluoride in inorganic salts of the integument of Antarctic krill (Euphausia superba). Scientific Reports, 9(1), 7853. http://dx.doi.org/10.1038/s41598-019-44337-6. PMid:31133736.

Peters, G., Saborowski, R., Buchholz, F., \& Mentlein, R. (1999). Two distinct forms of the chitin-degrading enzyme $\mathrm{N}$-acetyl- $\beta$ - $\mathrm{D}$ glucosaminidase in the Antarctic krill: specialists in digestion and moult. Marine Biology, 134(4), 697-703. http://dx.doi.org/10.1007/ s002270050585.

Rigueira, L. M. B., Lana, D. A. P. D., Santos, D. M., Pimenta, A. M., Augusti, R., \& Costa, L. M. (2016). Identification of metal binding to proteins in seed samples using RF-HPLC-UV, GFAAS and MALDITOF-MS. Food Chemistry, 211, 910-915. http://dx.doi.org/10.1016/j. foodchem.2016.05.061. PMid:27283712.

Sands, M., Nicol, S., \& Mcminn, A. (1998). Fluoride in Antarctic marine crustaceans. Marine Biology, 132(4), 591-598. http://dx.doi. org/10.1007/s002270050424.

Seear, P. J., Tarling, G. A., Burns, G., Goodallcopestake, W. P., Gaten, E., Ozkaya, O., \& Rosato, E. (2010). Differential gene expression during the moult cycle of Antarctic krill (Euphausia superba). BMC Genomics, 11(1), 582-582. http://dx.doi.org/10.1186/1471-2164-11582. PMid:20958982.

Spindler, K. D., \& Buchholz, F. (1988). Partial characterization of chitin degrading enzymes from two Euphausiids, Euphausia superba and Meganyctiphanes norvegica. Polar Biology, 9(2), 115-122. http:// dx.doi.org/10.1007/BF00442038.

Spindler-Barth, M. (1976). Changes in the chemical composition of the common shore crab, Carcinus maenas, during the molting cycle. Journal of Comparative Physiology, 105(2), 197-205. http://dx.doi. org/10.1007/BF00691122.

Sun, R., Liu, X., Yu, Y., Miao, J., Leng, K., \& Gao, H. (2021). Preparation process optimization, structural characterization and in vitro digestion stability analysis of Antarctic krill (Euphausia superba) peptides-zinc chelate. Food Chemistry, 340, 128056. http://dx.doi. org/10.1016/j.foodchem.2020.128056. PMid:33032152. 
Torrecillas, S., Montero, D., Carvalho, M., Benitez-Santana, T., \& Izquierdo, M. (2021). Replacement of fish meal by Antarctic krill meal in diets for European sea bass Dicentrarchus labrax: Growth performance, feed utilization and liver lipid metabolism. Aquaculture, 545, 737166. http://dx.doi.org/10.1016/j.aquaculture.2021.737166.

Turkiewicz, M., Kalinowska, H., Zielińska, M., \& Bielecki, S. (2000). Purification and characterization of two endo-1,4- $\beta$-xylanases from Antarctic krill, Euphausia superba Dana. Comparative Biochemistry and Physiology. Part B, Biochemistry \& Molecular Biology, 127(3), 325-335. http://dx.doi.org/10.1016/S0305-0491(00)00268-6. PMid:11126763.

Yao, Q., Lin, Q., Yan, S. A., Huang, M., \& Chen, L. (2021). Dietary risk assessment of fluoride, lead, chromium, and cadmium through consumption of Tieguanyin tea and white tea. Food Science and Technology, 41(3), 782-789. http://dx.doi.org/10.1590/fst.69220.

Young, V. R., \& Pellett, P. L. (1991). Protein evaluation, amino acid scoring and the Food and Drug Administration's proposed food labeling regulations. The Journal of Nutrition, 121(1), 145-150. http:// dx.doi.org/10.1093/jn/121.1.145. PMid:1992052.

Zhang, H. Y., Cao, M. X., Fodjo, E. K., Kong, C., Cai, Y. Q., Shen, X. S., \& Chen, X. Z. (2018). Safety of Antarctic krill (Euphausia superba) as food source: its initial fluoride toxicity study. Food Science and Technology, 39(5), 905-911. http://dx.doi.org/10.1590/fst.11418.

Zhou, T., Wang, X., Yan, J., \& Li, Y. (2018). Gene analysis and structure prediction for the cold-adaption mechanism of trypsin from the Krill, Euphausia superba (dana, 1852). Journal of the Science of Food and Agriculture, 98(8), 3049-3056. http://dx.doi.org/10.1002/ jsfa.8804. PMid:29194642.

Zielkowski, R., \& Spindler, K. D. (1978). Chitinase and chitobiase from the integument of Locusta migratoria: characterization and titer during the fifth larval instar. Insect Biochemistry, 8(1), 67-71. http://dx.doi.org/10.1016/0020-1790(78)90012-4. 